\title{
Effect of Cigarette Smoking on Serum Homocysteine and Vitamin B12 Level in Male Population of Udaipur
}

\section{Deepa Singh}

American International Institute of Medical Sciences, Udaipur, India

*Corresponding author: Deepa Singh, American International Institute of Medical Sciences, Udaipur, India, Tel: 09829993266; E-mail: dc_deepa@rediffmail.com Rec date: Jun 22, 2016; Acc date: Jun 27, 2016; Pub date: Jun 30, 2016

Copyright: (c) 2016 Singh D. This is an open-access article distributed under the terms of the Creative Commons Attribution License, which permits unrestricted use, distribution, and reproduction in any medium, provided the original author and source are credited.

\begin{abstract}
Cigarette smoking is known to be associated with increased plasma Homocysteine. Both known to be associated with increased risk of cardiovascular disease. This study investigated the effect of smoking on serum Homocysteine and vitamin B12 concentration. Serum Homocysteine and vitamin B12 levels were measured in 300 male subjects. Out of which 150 were smokers and 150 non-smokers (controls) with an age range of 50 to 60 years. Only chronic smokers who were smoking for more than 20 years were included in the study. The concentration of Homocysteine in smokers was $17.51 \pm 7.44 \mu \mathrm{mol} / \mathrm{L}$ and in non-smokers was $8.61 \pm 5.32 \mu \mathrm{mol} / \mathrm{L}$. Instead the concentration of vitamin B12 in smokers was $346.83 \pm 125.76 \mathrm{pg} / \mathrm{ml}$ and in non-smokers was $481.43 \pm 174.65 \mathrm{pg} / \mathrm{ml}$. There was significant increase in concentration of Homocysteine in serum of chronic smokers as compared to non-smokers while it was inverse in case of vitamin B12. The concentration of vitamin B12 was significantly decreased in serum of chronic smokers as compared to non-smokers. Thus this study concludes that smoking increases Homocysteine levels and decreases vitamin B12 levels leading to increase cardiovascular disease risk among smokers.
\end{abstract}

Keywords: Smoking; Homocysteine; Vitamin B12; Cardiovascular disease

\section{Introduction}

Cardiovascular disease is among the leading cause of death in developed countries. Cigarette smoking is one of the major risk factors in cardiovascular diseases for both males and females. Up to $50 \%$ of the avoidable deaths in the industrialized world have been attributed to smoking, half of which show cardiovascular disease. Endothelial injury is considered to be a key initiating event in the pathogenesis of atherosclerosis [1]. It is possible that cigarette smoking may exert its effect through endothelial damage [2].

Cigarette smoking is known to be associated with a raised plasma Homocysteine level [3-8]. Smokers also tend to have lower levels of Bvitamins, folate, vitamin B6 and vitamin B12 [4,5,9], all of which affect Homocysteine levels by acting as cofactors (vitamin B6 and B12) or cosubstrate (folate) for the enzymes controlling Homocysteine metabolism [10-15]. Elevated levels of total Homocysteine has emerged as an important risk factor in the assessment of cardiovascular disease [16-18]. Excess Homocysteine in the blood stream may cause injuries to arterial vessels due to its irritant nature, and result in inflammation and plaque formation, which may eventually cause blockage of blood flow to the heart. Therefore, Hyper Homocysteinemia has been considered as an independent risk factor of coronary artery disease (CAD). A positive association between elevated plasma total Homocysteine levels and a number of cardiovascular risk factors, smoking, particularly, was shown in study conducted in Norway [19]. It has already been reported about an amplifying effect of cigarette smoking on Homocysteine associated cardiovascular risk [20].

The aim of this study is to investigate the effect of cigarette smoking on plasma Homocysteine and vitamin B12 concentrations in males of Udaipur city.

\section{Materials and Methods}

A total number of 300 subjects were evaluated at Arth Diagnostics Private Limited, Udaipur. 150 male chronic cigarette smokers who were smoking for more than 20 years, with an age range of 50 to 60 years, were included for this study after obtaining written informed consent (Group I). 150 male non-smokers, whom age and weight was approximately matched with the subjects in (Group I) were recruited as controls (Group II). Controls were clinically healthy and from a similar background to cases as possible.

The following criteria were used for exclusion:

1. Alcoholics

2. Ex-smokers

3. Diabetes mellitus

4. Renal disease

5. Hypertension

6. Previous and family history of coronary heart disease

7. Acute infection

8. Chronic hepatic dysfunction

9. Nutritional derangements

\section{Malignancies}

All patients were free of drugs which would influence the plasma Homocysteine levels including multivitamins. Venous blood samples were collected after 12 hours of an overnight fast into plain tubes. Serum was obtained by centrifugation and samples were immediately separated into aliquot and stored at $-20^{\circ} \mathrm{C}$ until analysed. Homocysteine levels were analysed by enzymatic assay on fully autoanalyser of Roche, Cobas Integra 400 and its reference range was 4.44-13.56 $\mu \mathrm{mol} / \mathrm{L}$ and vitamin B12 concentrations were analysed by 
Page 2 of 3

chemiluminescence (Elecsys) immunoassay of Roche, Cobas e411 and its reference range varied between $200-835 \mathrm{pg} / \mathrm{ml}$ for adults.

Vitamin B12 is an essential cofactor for two enzymes involved in one-carbon metabolism: methylmalonyl-CoA-mutase (reduced function of this enzyme results in increased serum methylmalonic acid (MMA) levels) and methionine synthetase (this enzyme catalyzes the remethylation of Homocysteine to methionine). A serum B12 level below the normal expected range may indicate B12 deficiency. However, a B12 level within the low normal range does not exclude B12 deficiency; symptomatic patients need to be further evaluated with MMA, folic acid, and Homocysteine. The Elecsys vitamin B12 assay employs a competitive test principle using intrinsic factor specific for vitamin B12. Vitamin B12 in the sample competes with the added vitamin B12 labelled with biotin for the binding sites on the ruthenium-labelled intrinsic factor complex.
Homocysteine is a thiol containing amino acid produced by the intracellular demethylation of methionine. Total Homocysteine represents the sum of all forms of Homocysteine incuding forms of oxidized, protein-bound and free. Homocysteine Enzymatic Assay is based on a novel enzyme cycling assay principle that assesses the cosubstrate conversion product instead of assessing co-substrate or Homocysteine conversion products of Homocysteine.

\section{Results}

As shown in Table 1, serum Homocysteine concentrations were significantly higher in smokers than in non-smokers. Also, there was significant variation in the levels of vitamin B12 in both the groups as shown in Table 2. Vitamin B12 concentrations were significantly lower in smokers as compared to non-smokers.

\begin{tabular}{|l|l|l|l|}
\hline & Group I & Group II & p-value \\
\hline & $\begin{array}{l}\text { Smokers } \\
\text { (mean } \pm \text { SD) }\end{array}$ & $\begin{array}{l}\text { Non Smokers } \\
\text { (mean } \pm \text { SD) }\end{array}$ & \\
\hline $\begin{array}{l}\text { Homocysteine } \\
\mu \mathrm{mol} / \mathrm{L}\end{array}$ & $17.51 \pm 7.44$ & $8.61 \pm 5.32$ & $<0.05$ \\
\hline
\end{tabular}

Table 1: Serum homocysteine concentrations.

\begin{tabular}{|l|l|l|l|}
\hline & Group I & Group II & p-value \\
\hline & $\begin{array}{l}\text { Smokers } \\
\text { (Mean } \pm \text { SD) }\end{array}$ & $\begin{array}{l}\text { Non Smokers } \\
\text { (Mean } \pm \text { SD) }\end{array}$ & \\
\hline $\begin{array}{l}\text { Vitamin B12 } \\
\mathrm{pg} / \mathrm{ml}\end{array}$ & $346.83 \pm 125.76$ & $481.43 \pm 174.65$ & $<0.05$ \\
\hline
\end{tabular}

Table 2: Serum Vitamin B12 concentrations.

\section{Discussion}

In this study data revealed that in cigarette smokers, serum Homocysteine levels was almost double i.e., 103.3\% higher than nonsmokers. Several mechanisms might explain the increased risk in smokers with raised serum Homocysteine. Smoking affects the vascular tree via several different interactive mechanisms [21]. Nicotine and carbon monoxide separately produce tachycardia, hypertension and vasoconstriction and both produce direct endothelial damage. Smoking also affects vaso-occlusive factors such as platelet aggregation, plasma viscosity and fibrinogen levels [21]. Hyperhomocysteinaemia has been associated with impaired endothelial function and abnormal flow mediated vasodilation has been demonstrated with mild hyperhomocysteinaemia [22-24]. It may also damage the vascular tree via platelet activation, lipid peroxidation, enhanced tissue factor activation, reduced Von Willebrand factor; increased fibrinogen levels and smooth muscle proliferation [25]. The Hordaland [6-8] and other studies [3-5] have shown higher homocysteine levels in smokers, as well as in males and older subjects.

Data also showed serum vitamin B12 was $27.9 \%$ lower in smokers as compared to non-smokers. The results obtained in our study are in accordance with the results of those from Pagan et al [4] who found plasma vitamin $\mathrm{B} 12$ concentrations to be significantly lower in smokers than in non-smokers. Thus smoking affects the nutritional status of smokers. Subar et al. [26] have studied food and nutrient intake differences between smokers and non-smokers based on data from the Second National Health and Nutrition Survey (NHANES II) and found that smokers have a lower intake of most vitamins and were less likely to have consumed fruit, vegetables, vitamin and mineral supplements. In the Caerphilly Heart Disease Study [27] total nutrient intake was also found to be lower in smokers than in non-smokers.

\section{Conclusion}

Serum Homocysteine concentration was found to be significantly high in cigarette smokers as compared to non-smokers. In contrast, vitamin B12 levels were low in smokers which lead to derangement of Homocysteine metabolism. Thus, smokers with high serum Homocysteine concentration are at greatly increased risk of cardiovascular disease and should be counselled to help them cease smoking. In addition, supplementation of multivitamins may be appropriate for such chronic smokers.

\section{References}

1. De Jongh S, Lilien MR, Bakker HD, Hutten BA, Kastelein JJ, et al. (2002) Family history of cardiovascular events and endothelial dysfunction in children with familial hypercholesterolemia. Atherosclerosis 163: 193-197. 
2. Michael Pittilo R (2000) Cigarette smoking, endothelial injury and cardiovascular disease. Int J Exp Pathol 81: 219-230.

3. Reis RP, Azinheira J, Reis HP, Pina JE, Correia JM, et al. (2000) Influence of smoking on homocysteinemia at baseline and after methionine load. Rev Port Cardiol 19: 471-474.

4. Pagán K, Hou J, Goldenberg RL, Cliver SP, Tamura T (2001) Effect of smoking on serum concentrations of total homocysteine and $\mathrm{B}$ vitamins in mid-pregnancy. Clin Chim Acta 306: 103-109.

5. McCarty MF (2000) Increased homocysteine associated with smoking, chronic inflammation and aging may reflect acute phase induction of pyridoxal phosphatase activity. Med Hypotheses 55: 289-293.

6. Nygård O, Vollset SE, Refsum H, Stensvold I, Tverdal A, et al. (1995) Total plasma homocysteine and cardiovascular risk profile. The Hordaland Homocysteine Study. JAMA 274: 1526-1533.

7. Nygård O, Refsum H, Ueland PM, Vollset SE (1998) Major lifestyle determinants of plasma total homocysteine distribution: The Hordaland Homocysteine Study. Am J Clin Nutr 67: 263-270.

8. El-Khairy L, Ueland PM, Nygård O, Refsum H, Vollset SE (1999) Lifestyle and cardiovascular disease risk factors as determinants of total cysteine in plasma: the Hordaland Homocysteine Study. Am J Clin Nutr 70: 1016-1024.

9. Mansoor MA, Kristensen O, Hervig T et al. (1997) Low concentration of folate in serum and erythrocytes of smokers: methionine loading decreases folate concentrations in serum of smokers and non-smokers. Clin Chem 43: 2192-2194.

10. Vermaak WJ, Barnard HC, Potgieter GM, Theron HD (1987) Vitamin B6 and coronary artery disease. Epidemiological observations and case studies. Atherosclerosis 63: 235-238.

11. Kok FJ, Schrijver J, Hofman A, Witteman JC, Kruyssen DA, et al. (1989) Low vitamin B6 status in patients with acute myocardial infarction. Am J Cardiol 63: 513-516.

12. Ubbink JB, Vermaak WJ, Vander Merwe A, Becker PJ (1993) Vitamin B1, vitamin B6, and folate nutritional status in men with hyperhomocysteinemia. Am J Clin Nutr 57: 47-53.

13. Ryan M, Robinson K, Clarke R, Refsum HM, Ueland P, et al. (1993) Vitamin B6 and folate Homocysteine concentrations in coronary artery disease (Abstr). Ir J Med Sci 162: 197A.

14. Selhub J, Jacques PF, Wilson PW, Rush D, Rosenberg IH (1993) Vitamin status and intake as primary determinants of homocysteinemia in an elderly population. JAMA 270: 2693-2698.
15. Robinson K, Mayer EL, Miller DP, Green R, Van Lente F, et al. (1995) Hyper-homocysteinemia and low pyridoxal phosphate. Common and independent reversible risk factors for coronary artery disease. Circulation 92: 2825-2830.

16. Eikelboom JW, Lonn E, Genest J Jr, Hankey G, Yusuf S (1999) Homocyst(e)ine and cardiovascular disease: a critical review of the epidemiologic evidence. Ann Intern Med 131: 363-375.

17. Scott J, Weir D (1996) Homocysteine and cardiovascular disease. QJM 89: 561-563.

18. Nygård O, Nordrehaug JE, Refsum H, Ueland PM, Farstad M, et al. (1997) Plasma homocysteine levels and mortality in patients with coronary artery disease. N Engl J Med 337: 230-236.

19. Wilcken DE (2002) Homocysteine, smoking and vascular disease. Eur Heart J 23: 1559-1560.

20. O'Callaghan P, Meleady R, Fitzgerald T, Graham I (2002) European COMAC group: Smoking and plasma homocysteine. Eur Heart J 23: 1580-1586.

21. Bartecci CE, Mackenzie TD, Schrier RW (1994) The human costs of tobacco use. N Engl J Med 330: 975-980.

22. Harker LA, Ross R, Slichter SJ, Scott CR (1976) Homocystine-induced arteriosclerosis. The role of endothelial cell injury and platelet response in its genesis. J Clin Invest 58: 731-741.

23. Wall RT, Harlan JM, Harker LA, Striker GE (1980) Homocysteineinduced endothelial cell injury in vitro: a model for the study of vascular injury. Thromb Res 18: 113-121.

24. Nappo F, De Rosa N, Marfella R, De Lucia D, Ingrosso D, et al. (1999) Impairment of endothelial functions by acute hyperhomocysteinemia and reversal by antioxidant vitamins. JAMA 281: 2113-2118.

25. Tsai JC, Perrella MA, Yoshizumi M, Hsieh CM, Haber E, et al. (1994) Promotion of vascular smooth muscle cell growth by homocysteine: a link to atherosclerosis. Proc Natl Acad Sci USA 91: 6369-6373.

26. Subar AF, Harlan LC, Mattson ME (1990) Food and nutrient intake differences between smokers and non-smokers in the USA. Am J Public Health 80: 1323-1329.

27. Fehily AM, Phillips KM, Yarnell JW (1984) Diet, smoking, social class, and body mass index in the Caerphilly Heart Disease Study. Am J Clin Nutr 40: 827-833. 